\title{
Detection and Molecular Phylogenetic-Morphometric Characterization of Rhizoctonia tuliparum, Causal Agent of Gray Bulb Rot of Tulips and Bulbous Iris
}

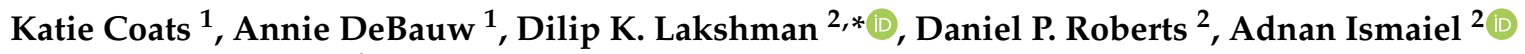 \\ and Gary Chastagner ${ }^{1, *}$
}

check for

updates

Citation: Coats, K.; DeBauw, A.;

Lakshman, D.K.; Roberts, D.P.;

Ismaiel, A.; Chastagner, G. Detection and Molecular Phylogenetic-

Morphometric Characterization of

Rhizoctonia tuliparum, Causal Agent

of Gray Bulb Rot of Tulips and

Bulbous Iris. J. Fungi 2022, 8, 163.

https://doi.org/10.3390/

jof8020163

Academic Editor: Willem Melchers

Received: 18 January 2022

Accepted: 3 February 2022

Published: 8 February 2022

Publisher's Note: MDPI stays neutral with regard to jurisdictional claims in published maps and institutional affiliations.

Copyright: (c) 2022 by the authors. Licensee MDPI, Basel, Switzerland. This article is an open access article distributed under the terms and conditions of the Creative Commons Attribution (CC BY) license (https:// creativecommons.org/licenses/by/ $4.0 /)$.
1 Department of Plant Pathology, Washington State University Research \& Extension Center, 2606 West Pioneer, Puyallup, WA 98371, USA; Coatskp@puyallup.k12.wa.us (K.C.); annie.debauw@oda.oregon.gov (A.D.)

2 Sustainable Agricultural Systems Laboratory, USDA-ARS, 10300 Baltimore Avenue, Beltsville, MD 20705, USA; dan.roberts@usda.gov (D.P.R.); ed.ismaiel@usda.gov (A.I.)

* Correspondence: Dilip.Lakshman@usda.gov (D.K.L.); chastag@wsu.edu (G.C.)

\begin{abstract}
Gray bulb rot of tulips and bulbous iris is caused by the soil-borne fungal pathogen, Rhizoctonia tuliparum (Rtul). Sclerotia present in infected bulbs, as well as overwintering sclerotia in soil and field debris, are the primary sources of infection. A method for accurate and sensitive detection of Rtul from soil and infected bulbs, and estimation of inoculum threshold levels, is needed for the management of disease caused by this pathogen. We designed a unique set of primers targeting the ITS2 region of the Rtul genome and developed a highly sensitive quantitative PCR (qPCR)-based method for Rtul identification using these primers, where the threshold of detection was approximately $1 \mathrm{fg}$ Rtul DNA. The assay was more sensitive with sclerotia collected from the field (natural) than with those grown in the lab, and more sensitive with natural-light than natural-dark sclerotia. Also, the detection method was more sensitive when sclerotia were extracted from soil than from bulb tissue. The qPCR method was highly specific, as no PCR amplification was detected when genomic DNA from 62 non-Rtul Rhizoctonia isolates from a wide range of anastomosis groups were tested. To understand the evolutionary relationships and genomic diversity of Rtul, we performed phylogenetics of the ITS1-5.8S-ITS2 region and ITS2-molecular morphometric characterization (MMC) of Rtul isolates. The three Rtul isolates whose ITS sequences were available in GenBank formed a distinct phylogenetic clade with Ceratobasidium anceps as the nearest relative. Furthermore, MMC analysis revealed genetic divergence among these three $R t u l$ isolates.
\end{abstract}

Keywords: Sclerotium tuliparum; Ceratobasidium; quantitative PCR; soil-borne pathogen; sclerotia; ITS2 secondary structure; phylogeny; basidiomycete

\section{Introduction}

Gray bulb rot of tulips and bulbous iris is caused by the soil-borne fungal pathogen Rhizoctonia tuliparum (Rtul) [Whetzel and Arthur; Synonym: Sclerotium tuliparum (Kleb)] [1-6]. The disease was initially described by Wakker [7] in the Netherlands, and the pathogen was described by Whetzel and Arthur [8]. Gray bulb rot is primarily a problem in field or landscape-grown tulips and irises, but the pathogen has also been reported in daffodil, crocus, gladiolus, and lily [9]. The fungus forms felty masses between the scales, and infected bulbs rot from the top down. Both the bulbs and roots turn grayish in color and progressively dry and shrivel at the site of infection. Infected shoots either fail to emerge or die shortly after infection during late winter. If a plant does grow, it is usually slow to develop and withers and dies before flowering [9]. Diseased plants tend to occur in patches in field and landscape plantings, but this disease can completely destroy the crop after several rotations if unmanaged. 
Other than volunteer plants, overwintering sclerotia of $R t u l$ residing in soil and host debris are important sources of inoculum. Sclerotia range in size from 1-10 $\mathrm{mm}$ in diameter and are formed on infected plant material. They turn from white to dark brown or black as they ripen and can be found on bulbs and in surrounding soil. According to Coley-Smith et al. [10], about $10 \%$ of the sclerotia can remain viable in soil for at least ten years. Sclerotia usually remain attached to soil and plant debris when the bulbs are dug, allowing them to be easily spread from field to field by cultivating equipment. The pathogen can also be spread by the movement of infected planting stock.

Currently, there are no reliable and rapid assay methods to assess inoculum levels of Rtul in the soil and on infected bulbs [11-13]. The ability to quantify inoculum levels of $R t u l$ in the soil and on planting stock, coupled with information on inoculum threshold levels necessary for disease development, may allow for the development of predictive diagnostic tests to identify high-risk fields and planting stocks where inoculum of this pathogen is above threshold values [14-17]. Access to this type of information would assist growers in making management decisions relating to the application of chemical or other control measures and potentially reduce the use of fungicides in the production of tulips and iris [13]. Therefore, we developed a sensitive and specific quantitative PCR (qPCR) assay [18] to detect Rtul and tested its effectiveness with bulb and soil samples.

The nuclear status and the teleomorph of the anamorphic fungus Rtul have not been unambiguously resolved; isolates from the UK [19] and Netherlands [20] having been reported to be binucleate, potentially placing Rtul as Ceratobasidium sp. Therefore, we determined the phylogenetic status of Rtul within the Ceratobasidiaceae using the ribosomal internal transcribed spacer (ITS1-5.8S-ITS2). To gain information on the evolutionary relationships and genomic diversity of $R t u l$, we also characterized the ITS2-primary and secondary structure-based molecular morphometrics (MMC) of isolates currently available in GenBank [21,22].

\section{Materials and Methods}

\subsection{Fungal isolates}

The fungal isolates used in this study are listed in Table 1. Isolate I-399 of Rtul was obtained in 1998 from infested soil from a commercial bulbous iris field near Mount Vernon, WA. The other Rtul isolates were collected in 2008 and 2012 from symptomatic bulbous irises grown near Puyallup, WA. Agar plugs of Rtul were retrieved from long-term storage at $4{ }^{\circ} \mathrm{C}$ in water, transferred to potato dextrose agar (PDA), and cultures of Rtul maintained on PDA at room temperature prior to DNA extraction. The sixty-two non-Rtul isolates used for specificity testing in qPCR assays were stored on filter paper and held at room temperature prior to DNA extraction.

\subsection{DNA Extraction from Fungal Isolates, Soil, and Plant Tissue}

DNA was extracted from homogenized fungal isolates using a Gentra Puregene Tissue Kit (QIAGEN, Valencia, CA, USA), following the manufacturer's instructions. Sclerotia and/or mycelia were homogenized (FastPrep-24 Homogenizer, MP Biomedicals, Santa Ana, CA, USA) at maximum speed for one $\min$ in $2 \mathrm{~mL}$ microcentrifuge tubes containing six 3.5-mm-diameter glass beads (BioSpec Products, Bartlesville, OK, USA).

Soil samples were collected from the top $10 \mathrm{~cm}$ of a Puyallup fine sandy loam field site at the Washington State University Research and Extension Center in Puyallup, air dried, passed through a 2-mm sieve, and stored at room temperature. Soil was autoclaved at $125^{\circ} \mathrm{C}$ for 40 min prior to DNA extraction. DNA was extracted using the Wizard Magnetic DNA Purification System for Food (Cat. No. PRFF3750; Promega, Madison, WI, USA) with Lysis Buffer A replaced by Soil Extraction Buffer (SEB; $120 \mathrm{mM}$ sodium phosphate buffer, $\mathrm{pH} 8,2 \% \mathrm{CTAB}, 1.5 \mathrm{M} \mathrm{NaCl}, 2 \%$ antifoam $\mathrm{B}$ emulsion). Soil samples were mixed to homogeneity and triplicate $4 \mathrm{-g}$ samples weighed and added to $50 \mathrm{~mL}$ tubes containing $16 \mathrm{~mL}$ SEB and $5 \mathrm{~mL} 3.5-\mathrm{mm}$-diameter glass beads. Samples were then homogenized at maximum speed for one min and centrifuged at $2000 \times g$ for three min. Supernatant 
$(500 \mu \mathrm{L}$ ) was transferred to $2 \mathrm{~mL}$ microcentrifuge tubes containing $250 \mu \mathrm{L}$ Buffer B (Cat. No. Z3191, Promega) using $200 \mathrm{mg}$ of starting material (manufacturer's instructions were followed starting from Step 3). DNA samples were stored at $4{ }^{\circ} \mathrm{C}$ until qPCR analysis.

Table 1. Fungal isolates used to test species specificity of the TaqMan qPCR assay for Rhizoctonia tuliparum, and their resulting Rtul cycle threshold $\left(\mathrm{C}_{\mathrm{t}}\right)$ value.

\begin{tabular}{|c|c|c|c|c|}
\hline Isolate & Species & Host/Source & Origin & $C_{t}$ Value \\
\hline PC76 & Rhizoctonia solani AG-2-1 & Tulip & Washington & $\mathrm{N} / \mathrm{A}^{\mathrm{a}}$ \\
\hline Rh060811 c & R. solani AG 2-1 & Pea & Washington & $\mathrm{N} / \mathrm{A}$ \\
\hline Rh070913 c & R. solani AG 2-1 & Onion & Washington & $\mathrm{N} / \mathrm{A}$ \\
\hline $\mathrm{Rh} 070937^{\mathrm{c}}$ & R. solani AG 2-1 & Pea & Washington & $\mathrm{N} / \mathrm{A}$ \\
\hline $\mathrm{Rh} 070933^{\mathrm{c}}$ & R. solani AG 3 & Potato & Washington & $\mathrm{N} / \mathrm{A}$ \\
\hline Rh070934 c & R. solani AG 3 & Potato & Washington & $\mathrm{N} / \mathrm{A}$ \\
\hline Rh070935 c & R. solani AG 3 & Onion & Washington & $\mathrm{N} / \mathrm{A}$ \\
\hline Rh070942 c & R. solani AG 3 & Pea & Washington & $\mathrm{N} / \mathrm{A}$ \\
\hline Rh070912 c & R. solani AG 3 & Onion & Washington & $\mathrm{N} / \mathrm{A}$ \\
\hline Rh010901 c & R. solani AG 4 & Pea & Washington & $\mathrm{N} / \mathrm{A}$ \\
\hline $\mathrm{Rh} 070908^{\mathrm{c}}$ & R. solani AG 4 & Pea & Washington & $\mathrm{N} / \mathrm{A}$ \\
\hline Rh070909 c & R. solani AG 4 & Pea & Washington & $\mathrm{N} / \mathrm{A}$ \\
\hline Rh070910 c & R. solani AG 4 & Pea & Washington & $\mathrm{N} / \mathrm{A}$ \\
\hline Rh070915 c & R. solani AG 4 & Onion & Washington & $\mathrm{N} / \mathrm{A}$ \\
\hline Rh070929 c & R. solani AG 4 & Onion & Washington & $\mathrm{N} / \mathrm{A}$ \\
\hline Rh070939 c & R. solani AG 4 & Onion & Washington & $\mathrm{N} / \mathrm{A}$ \\
\hline Rh070940 c & R. solani AG 4 & Potato & Washington & $\mathrm{N} / \mathrm{A}$ \\
\hline Rh070930 c & R. solani AG 5 & Potato & Washington & $\mathrm{N} / \mathrm{A}$ \\
\hline Rh070931 c & R. solani AG 5 & Pea & Washington & $\mathrm{N} / \mathrm{A}$ \\
\hline Rh070932 c & R. solani AG 5 & Potato & Washington & $\mathrm{N} / \mathrm{A}$ \\
\hline Rh080714 c & R. solani AG 8 & Wheat & Washington & $\mathrm{N} / \mathrm{A}$ \\
\hline Rh010911 c & R. solani AG 8 & Onion & Washington & $\mathrm{N} / \mathrm{A}$ \\
\hline Rh070922 c & R. solani AG 8 & Soil ${ }^{d}$ & Washington & $\mathrm{N} / \mathrm{A}$ \\
\hline Rh070927 c & R. solani AG 8 & Onion & Washington & $\mathrm{N} / \mathrm{A}$ \\
\hline Rh070943 c & R. solani AG 8 & Pea & Washington & $\mathrm{N} / \mathrm{A}$ \\
\hline Rh100557 c & R. solani AG 8 & Wheat & Washington & $\mathrm{N} / \mathrm{A}$ \\
\hline Rh070921 c & R. solani AG 9 & Pea & Washington & $\mathrm{N} / \mathrm{A}$ \\
\hline Rh070938 c & R. solani AG 9 & Pea & Washington & $\mathrm{N} / \mathrm{A}$ \\
\hline Rh090801 ${ }^{\mathrm{c}}$ & Ceratobasidium AG-A & Onion & Washington & $\mathrm{N} / \mathrm{A}$ \\
\hline Rh010913 c & Ceratobasidium AG-A & Onion & Washington & $\mathrm{N} / \mathrm{A}$ \\
\hline $\mathrm{Rh} 070923^{\mathrm{c}}$ & Ceratobasidium AG-E & Soil ${ }^{d}$ & Washington & $\mathrm{N} / \mathrm{A}$ \\
\hline Rh110712 c & Ceratobasidium AG-I & Wheat & Washington & $\mathrm{N} / \mathrm{A}$ \\
\hline Rh070716 c & Ceratobasidium AG-I & Wheat & Washington & $\mathrm{N} / \mathrm{A}$ \\
\hline Rh070914 c & Ceratobasidium AG-I & Pea & Washington & $\mathrm{N} / \mathrm{A}$ \\
\hline Rh010905 c & Ceratobasidium sp. & Onion & Washington & $\mathrm{N} / \mathrm{A}$ \\
\hline Rh010909 c & Waitea circinata $($ R. oryzae grp. 1$)$ & Onion & Washington & $\mathrm{N} / \mathrm{A}$ \\
\hline Rh070924 c & W. circinata (var. circinata) & Soil ${ }^{d}$ & Washington & $\mathrm{N} / \mathrm{A}$ \\
\hline Rh070925 c & W. circinata (var. circinata) & Soil ${ }^{\mathrm{d}}$ & Washington & $\mathrm{N} / \mathrm{A}$ \\
\hline Rh070936 c & W. circinata (var. circinata) & Onion & Washington & $\mathrm{N} / \mathrm{A}$ \\
\hline Rh070911 c & Ceratobasidium sp. & Pea & Washington & $\mathrm{N} / \mathrm{A}$ \\
\hline $\mathrm{Rh} 070926^{\mathrm{c}}$ & Rhizoctonia spp. & Soil ${ }^{d}$ & Washington & $\mathrm{N} / \mathrm{A}$ \\
\hline $\mathrm{Rh} 070928^{\mathrm{c}}$ & Rhizoctonia spp. & Onion & Washington & $\mathrm{N} / \mathrm{A}$ \\
\hline VSP $05-01 \mathrm{~A}^{\mathrm{c}}$ & R. solani AG 4, HG II & Onion & Columbia Basin & $\mathrm{N} / \mathrm{A}$ \\
\hline VSP $05-01 \mathrm{~B}^{\mathrm{c}}$ & R. solani AG 4, HG II & Onion & Columbia Basin & $\mathrm{N} / \mathrm{A}$ \\
\hline VSP $05-37 A^{c}$ & & Swiss Chard & Washington & $\mathrm{N} / \mathrm{A}$ \\
\hline VSP $05-37 \mathrm{~B}^{\mathrm{c}}$ & & Swiss Chard & Washington & $\mathrm{N} / \mathrm{A}$ \\
\hline VSP 06-26 B ${ }^{\mathrm{c}}$ & R. solani AG 4, HG II & Onion & Columbia Basin & $\mathrm{N} / \mathrm{A}$ \\
\hline VSP $08-13 \mathrm{~A}^{\mathrm{c}}$ & & Onion & Columbia Basin & $\mathrm{N} / \mathrm{A}$ \\
\hline VSP $08-14 \mathrm{~B}^{\mathrm{c}}$ & & Onion & Columbia Basin & $\mathrm{N} / \mathrm{A}$ \\
\hline VSP 08-19 $\mathrm{A}^{\mathrm{c}}$ & & Onion & Columbia Basin & $\mathrm{N} / \mathrm{A}$ \\
\hline
\end{tabular}


Table 1. Cont.

\begin{tabular}{|c|c|c|c|c|}
\hline Isolate & Species & Host/Source & Origin & $C_{t}$ Value \\
\hline VSP 08-19 G ${ }^{c}$ & & Onion & Columbia Basin & $\mathrm{N} / \mathrm{A}$ \\
\hline VSP 08-33 B, plt $4^{c}$ & & Skullcap & Columbia Basin & $\mathrm{N} / \mathrm{A}$ \\
\hline 06SPFWLA ${ }^{\mathrm{c}}$ & R. solani AG 3 & Spinach & Washington & $\mathrm{N} / \mathrm{A}$ \\
\hline VSP 08-33 A, plt $6^{c}$ & R. solani & Skullcap & Columbia Basin & $\mathrm{N} / \mathrm{A}$ \\
\hline VSP $10-20$ Tamara $1^{c}$ & R. solani & Onion & Columbia Basin & $\mathrm{N} / \mathrm{A}$ \\
\hline VSP $10-20$ Tamara $2^{c}$ & R. solani & Onion & Columbia Basin & $\mathrm{N} / \mathrm{A}$ \\
\hline VSP $10-20$ Field $2-2^{c}$ & R. solani & Onion & Columbia Basin & $\mathrm{N} / \mathrm{A}$ \\
\hline VSP $10-20$ Field $2-3^{c}$ & R. solani & Onion & Columbia Basin & $\mathrm{N} / \mathrm{A}$ \\
\hline $\operatorname{LP} 3^{c}$ & R. solani & Pea & Oregon & $\mathrm{N} / \mathrm{A}$ \\
\hline $\operatorname{LP} 10^{c}$ & R. solani & Pea & Oregon & $\mathrm{N} / \mathrm{A}$ \\
\hline $\mathrm{LP} 12^{\mathrm{c}}$ & R. solani & Pea & Oregon & $\mathrm{N} / \mathrm{A}$ \\
\hline $\operatorname{LP} 13^{c}$ & R. solani & Pea & Oregon & $\mathrm{N} / \mathrm{A}$ \\
\hline MBL12140 & R. tuliparum & Iris & Washington & 19.60 \\
\hline MBL12141 & R. tuliparum & Iris & Washington & 16.10 \\
\hline MBL12145 & R. tuliparum & Iris & Washington & 27.25 \\
\hline MBL12146 & R. tuliparum & Iris & Washington & 17.84 \\
\hline MBL11082 (DGF2_VV) & R. tuliparum & Iris & Washington & 33.51 \\
\hline Rh_Tulip & R. tuliparum & Tulip & Washington & 13.93 \\
\hline $\mathrm{I}-399 \mathrm{~b}$ & R. tuliparum & Iris & Washington & \\
\hline $\mathrm{I}-399$ & R. tuliparum 1:10 & Iris & Washington & 18.79 \\
\hline I-399 & R. tuliparum 1:100 & Iris & Washington & 21.32 \\
\hline I-399 & R. tuliparum 1:1000 & Iris & Washington & 24.90 \\
\hline No template control ${ }^{\mathrm{e}}$ & - & - & - & $\mathrm{N} / \mathrm{A}$ \\
\hline
\end{tabular}

${ }^{a}$ N/A = no amplification; ${ }^{b}$ I-399 DNA used for standard curve; ${ }^{c}$ Cultures provided by Lindsey du Toit, Washington State University, Mount Vernon Northwestern Washington Research and Extension Center; ${ }^{\mathrm{d}}$ Isolated

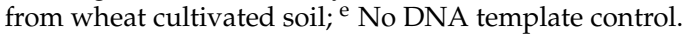

Tulip bulbs (Tulipa gesneriana var. Advent) from a Washington farm were harvested in 2013. Bulbs were surface sterilized with a $0.825 \%$ hypochlorite solution, rinsed twice with water, and homogenized to a textured paste consistency. Tulip tissue was kept frozen at $-20^{\circ} \mathrm{C}$ prior to DNA extraction. DNA was extracted with the Wizard Magnetic DNA Purification System for Food with SEB modification, as described above.

\subsection{Primer Design and qPCR Assay for R. tuliparum}

Sequence of the ribosomal DNA ITS region of the Rtul isolates (GenBank accessions KX767078, KX767079, KX767080) were compared among themselves and to a variety of Rhizoctonia sequences available in GenBank. Several sequence spans were identified that were conserved within the Rtul isolates but variable in other Rhizoctonia species. Three sets of primers and TaqMan ${ }^{\circledR}$ MGB probes potentially specific to $R t u l$ were designed using Primer Express Software Version 3.0 (Applied Biosystems, Foster City, CA, USA) and tested. The primer/probe set selected for further experimentation was designated as "Rtul" and amplified a 100-bp fragment of ITS (Table 2; Figure S1). The Rtul hybridization probe was labeled at the $5^{\prime}$ end with tetrachlorofluorescein (TET $\left.{ }^{\mathrm{TM}}\right)$ and at the $3^{\prime}$ end with a minor groove binder nonfluorescent quencher (MGB-NFQ) following the manufacturer's instructions (Applied Biosystems, Bedford, MA, USA). qPCR was carried out at the default cycling parameters of $50{ }^{\circ} \mathrm{C}$ for $2 \mathrm{~min}, 95^{\circ} \mathrm{C}$ for $10 \mathrm{~min}, 40$ cycles at $95^{\circ} \mathrm{C}$ for $15 \mathrm{~s}$, and $60^{\circ} \mathrm{C}$ for 1 min on a 7500 Real Time PCR System (Applied Biosystems) using Sequence Detection Software Version 1.3.1. An exogenous amplification control (EAC) of salmon testes DNA spiked into each reaction to measure potential amplification inhibition was detected by Sketa primers and a Sketa TaqMan ${ }^{\circledR}$ probe [23] labeled at the $5^{\prime}$ end with fluorescein (6FAM) dye and at the $3^{\prime}$ end with a tetramethylrhodamine (TAMRA ${ }^{\mathrm{TM}}$ ) quencher (Thermo Fisher Scientific, Waltham, MA, USA). The qPCR mixture $(25 \mu \mathrm{L})$ included $12.5 \mu \mathrm{L}$ TaqMan ${ }^{\circledR}$ Universal Master Mix II no AmpErase UNG; $100 \mathrm{nM}$ each Rtul primers, Rtul probe, EAC

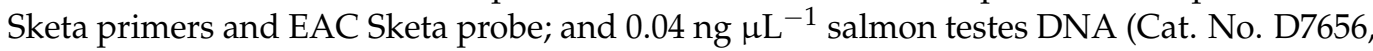
Sigma Chemical Co., St. Louis, MO, USA). Standard curves were generated based on 
linear regression of $C_{t}$ values produced by a dilution series of I-399 Rtul DNA containing $7.7 \times 10^{-2}$ to $7.7 \times 10^{-6}$ ng DNA. Rtul DNA quantity in unknown samples was calculated by applying their cycle threshold $\left(C_{t}\right)$ value as the independent variable in the resulting linear regression equation. Sterile water in place of the DNA template was run as the negative control. To determine the lowest threshold of detection with the Rtul primer/probe set, the concentration of DNA sample extracted from a pure culture of Rtul (DGF2-VV) was estimated with a fluorometer (Thermo Fisher Scientific) and used to make a 1:10 serial

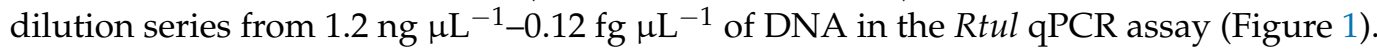
The amplification efficiency $(\mathrm{E})$ was calculated using the formula: $\mathrm{E}=10(-1 /$ slope $)-1$ (Ruijter et al. [24]). DNA samples, including standards and controls, were assayed in triplicate $(n=3)$.

Table 2. Primers and probes used for the TaqMan ${ }^{\circledR}$ quantitative PCR diagnostic assay for detection and quantification of Rhizoctonia tuliparum and the associated exogenous amplification control ${ }^{\text {a }}$.

\begin{tabular}{|c|c|c|c|}
\hline Primer/Probe Name & Sequence $\left(5^{\prime}-3^{\prime}\right)$ & Target Region & Study \\
\hline \multicolumn{4}{|c|}{ R. tuliparum primers } \\
\hline Rtul_for & CGAGGTCGACTTTTTGTTTTGG & ITS $^{\mathrm{a}}$ & This study \\
\hline Rtul_rev & CCGAGTGGAACCGAGTTCAC & ITS & This study \\
\hline \multicolumn{4}{|c|}{ R. tuliparum probe } \\
\hline \multicolumn{4}{|c|}{ R. tuliparum probe } \\
\hline Rtul_probe & [TET] TTTGCGGATTCACGTCC [MGB-NFQ] & ITS & This study \\
\hline & Sketa Exogenous Amplification Control (EAC) primers & & \\
\hline SketaF2 & GGTTTCCGCAGCTGGG & ITS & [23] \\
\hline SketaR3 & CCGAGCCGTCCTGGTCTA & ITS & [23] \\
\hline \multicolumn{4}{|l|}{ Sketa probe } \\
\hline SketaP2 & [6-FAM] AGTCGCAGGCGGCCACCGT [TAMRA] & ITS & [23] \\
\hline
\end{tabular}

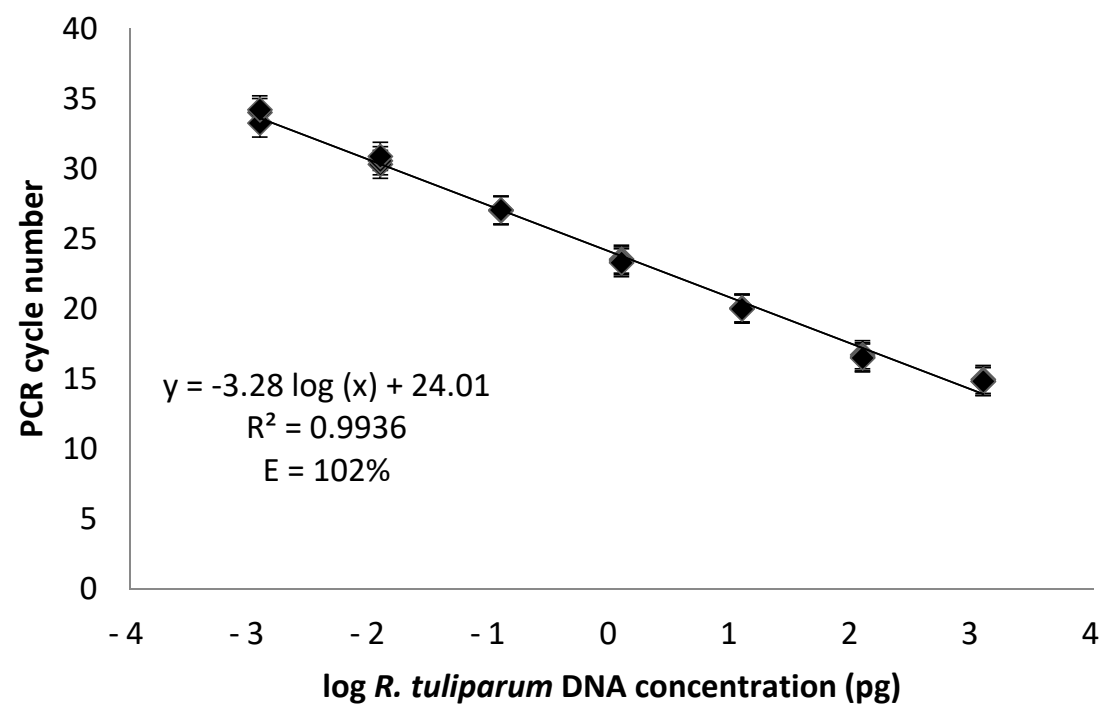

Figure 1. Determining the lowest threshold of detection with the Rtul primer/probe set used in this study. 1:10 serial dilution series (1.2 $\mathrm{ng} \mu \mathrm{L}^{-1}-0.12 \mathrm{fg} \mu \mathrm{L}^{-1}$ of DNA) of Rhizoctonia tuliparum (DGF2-VV) DNA analyzed in triplicate with qPCR. The log DNA concentration versus cycle threshold was plotted and a regression line drawn for the data.

\subsection{Detection of Lab-Grown and Field-Collected (Natural) Sclerotia of R. tuliparum}

Lab-grown sclerotia were prepared by transferring small cuttings of I-399 Rtul culture, containing mycelia and sclerotia, onto 10-cm-diameter PDA plates and incubating at $23^{\circ} \mathrm{C}$ in the dark. Sclerotia were removed from cultures on PDA plates with a sterile pipet tip after 
10 weeks and stored at room temperature. Natural sclerotia were obtained by manually sieving air-dried field soil (Puyallup fine sandy loam) which was collected 9 months after iris bulbs were planted in a field site that had been infested with Rtul inoculum on rice grains. Sclerotia were then stored in a vial at ambient temperature. Natural sclerotia ranged from brown to black in coloration and were categorized as light-colored or dark-colored (Figure S2). Due to the variability of sclerotia size and weight, 189 lab-grown sclerotia were weighed to determine the average weight of one sclerotium to be $1.78 \mathrm{mg}$. The amount of sclerotial material used in each experiment was a weight equivalent based on this number. DNA extracted from six replicates of eight $(14.25 \mathrm{mg})$ lab-grown, natural-light, and naturaldark sclerotia were analyzed in triplicate by Rtul qPCR undiluted and diluted with sterile water 1:10, 1:100, and 1:1000. Experiments were repeated and combined prior to analysis as there were no significant differences in results.

\subsection{Detection of R. tuliparum in Soil and Plant Samples}

For detection of Rtul in soil, the weight equivalent of one, two, four, eight, 16 and 32 lab-grown sclerotia were added to $4 \mathrm{~g}$ soil (Puyallup fine sandy loam field soil) samples in triplicate, prior to DNA extraction. DNA samples were diluted 1:1000 and analyzed with the Rtul/Sketa qPCR method described above in triplicate and the entire test repeated and results combined prior to analysis.

For the detection of Rtul in tulip tissue, the weight equivalent of eight lab-grown sclerotia was added to the weight equivalent of $1 / 8,1 / 4$, and $1 / 2$ tulip bulb in triplicate, and DNA was extracted as described above. The tunic was removed from thirty bulbs prior to determining mean bulb weight to be $20.78 \mathrm{~g}$. DNA samples were analyzed by Rtul/Sketa qPCR and compared to the equivalent treatment of sclerotia in the absence of bulb tissue.

\subsection{Phylogenetic Analyses}

The Rtul ITS sequences of our three GenBank submissions (GenBank accessions KX767078, KX767079, KX767080) were found to be identical through alignment and henceforth will be considered as the same haplotype, accession KX767078 being the largest of the sequences. Accession KX767078 was subjected to a BLAST search using the National Center for Bioinformatics Institute (NCBI) website. Sequences with high homology to KX767078, along with ITS sequences from known species of Ceratobasidum, Rhizoctonia solani (Thanatephorus cucumeris), and Waitea circinata were obtained in FASTA format, aligned using Clustal X [25], and manually adjusted using Mesquite editing software [26]. The final alignment file contained sequence from 34 isolates. Phylogenetic trees were constructed using Bayesian inference (BI) and maximum parsimony (MP) analyses. The Bayesian tree was obtained using MrBayes, Version 3.2.7 [27], using the general time reversible $(G T R+I+G, n s t=6)$ model with gamma distribution and invariable sites with default priors. Four chains and one million generations were run with a tree selected every 1000 generations. The initial $25 \%$ of trees were discarded during the burn-in phase. The remaining trees were used to produce a $50 \%$ majority rule consensus tree. This tree was edited and posterior probabilities above 0.95 placed above the branches. The MP tree was obtained with PAUP Version b10 software [28] using a heuristic search with a starting tree obtained via 1000 random stepwise addition sequences, and tree-bisection-reconnection as the branch-swapping algorithm, with MULTrees in effect. Bootstrap values were calculated with 1000 replicates. For both the Bayesian and MP trees, W. circinata var. agrostis was used as an outgroup based on the distance of the isolate from the rest of the isolates in the tree.

\subsection{Morphometric Analyses of the ITS2 Region}

For ITS2 structure analysis, the ITS1-5.8S-ITS2 sequences were retrieved for $C$. anceps isolates CBS 152.32 (GenBank accession MH855251) and CBS 152.32 (AJ427402), and three Rtul isolates: isolate I-399 (KX767078), the European isolate 29,792 (EU191041), and isolate from New York CBS206.25 (MH854847) [29]. The corresponding ITS2 sequences were identified utilizing the annotation utility of the ITS2 database [30]. Secondary structure 
was predicted with the prediction utility of the ITS2 database [30] and manually analyzed for morphometric features like compensatory base change (CBC), hemi-compensatory base change (hCBC), indels of base pairing, pseudoknot formation, and conserved loop sequences. Percent GC was estimated utilizing tools from PAUP Version b10 software [28].

\section{Results}

\subsection{R. tulipia qPCR Detection Assay Sensitivity and Specificity}

Analysis of the serial dilution standard curve showed a linear relationship $\left(R^{2}=0.994\right)$ between the log of the DNA concentration of Rtul and the cycle threshold $\left(\mathrm{C}_{t}\right)$ value over the seven most concentrated DNAs (i.e., $7.7 \times 10^{-2}$ to $7.7 \times 10^{-6} \mathrm{ng}$ ) (Figure 1). The least concentrated DNA sample used in the standard curve, at $0.12 \mathrm{fg}_{\mu} \mathrm{L}^{-1}$, was not detected and most likely indicates that the threshold of detection for this assay was approximately $1 \mathrm{fg} R t u l$ DNA. For determination of assay specificity, $62 \mathrm{non}-R t u l$ and six Rtul isolates of Rhizoctonia (Table 1) were analyzed to ensure that amplification occurs for all Rtul isolates and does not occur for any non-Rtul isolate. Tested isolates were from $R$. solani anastomosis groups (AGs) 2-1, 3, 4, 5, 8, and 9, and Ceratobasidium isolates from AGs A, E, and I, as well as $W$. circinata and several unidentified Rhizoctonia species. No amplification was observed with the 62 non-Rtul DNA samples, and $C_{t}$ values between 13.93 and 33.51 were observed for various Rtul DNA samples (Table 1).

\subsection{Detection of Lab-Grown and Natural Sclerotia}

Analysis of dilutions of DNA extracted from three types of sclerotia (lab-grown, natural-dark, and natural-light) revealed that the Rtul detection assay was more sensitive, in that it more efficiently detected Rtul DNA, when the DNA was diluted in the range of 1:10 to 1:1000 before qPCR (Figure 2). The Sketa internal amplification control confirmed that amplification was suppressed at higher DNA concentration levels. Three replicates each of DNA extracted from the weight equivalent of eight lab-grown, natural-dark, and naturallight sclerotia were diluted 1:1000 and analyzed by the Rtul qPCR assay to determine which type of sclerotia yielded more Rtul DNA (Figure 3). The natural-light sclerotia yielded an average of two and seven times more DNA than the natural-dark and the lab grown sclerotia, respectively.

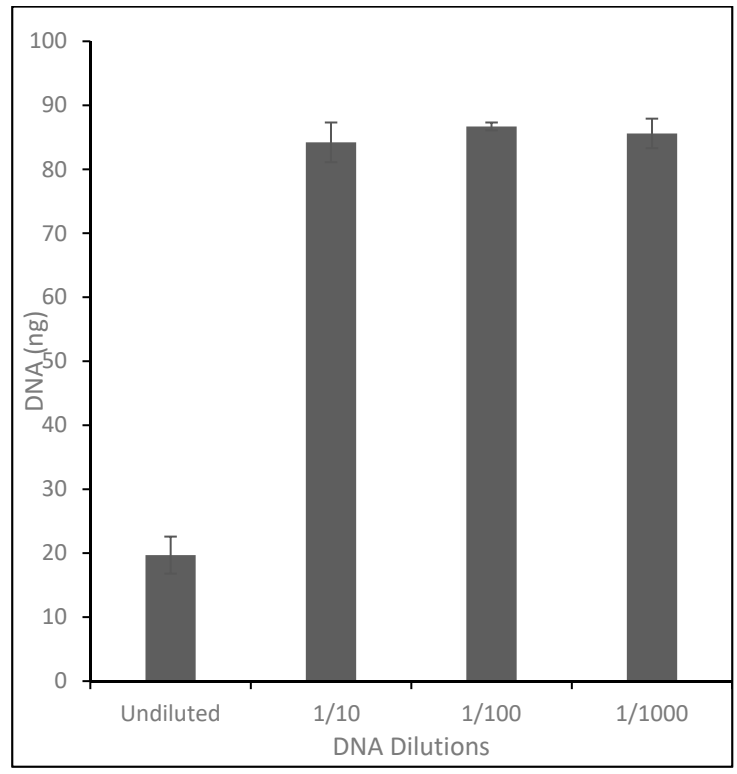

Figure 2. Effect of dilution on the sensitivity of detection of DNA from Rhizoctonia tuliparum sclerotia. DNAs extracted from lab-grown sclerotia in triplicate were diluted and analyzed by the Rtul qPCR assay, and the detected DNA for each dilution plotted. Error bars represent one standard deviation from the mean. The assays were more precise when the DNA was diluted in the range of 1:10 to 1:1000 before qPCR. 


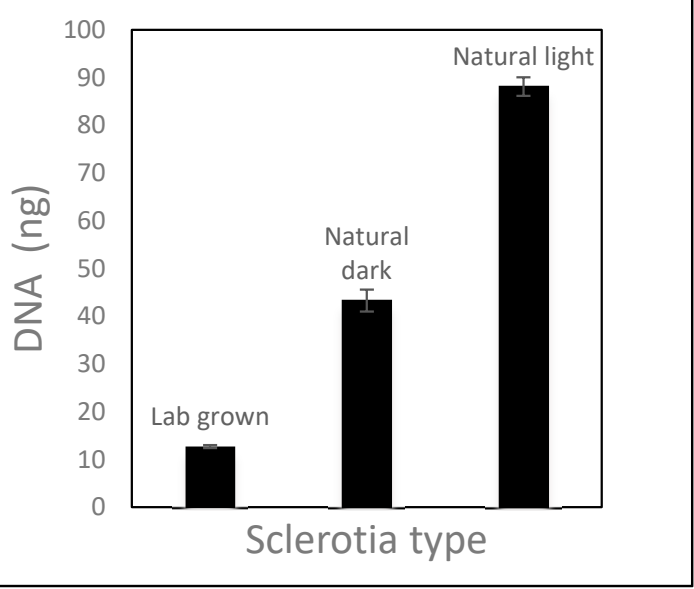

Figure 3. Sensitivity of detection of Rhizoctonia tuliparum DNA from lab-grown, natural-light, and natural-dark sclerotia. DNAs were extracted from $14.25 \mathrm{mg}$ sclerotia (equivalent of eight average size sclerotia) of three different types in triplicate diluted 1/1000 and analyzed by qPCR. The detected DNAs for each type were plotted in a bar chart with error bars representing one standard deviation from the mean.

\subsection{Detection of R. tuliparum in Soil}

Since sclerotia overwinter in soil, the utility of the qPCR method was evaluated by determining the amount of Rtul DNA from various numbers of sclerotia extracted from fixed quantities of soil. Weight equivalents of one, two, four, eight, and 16 lab-grown sclerotia did not yield significantly different Rtul qPCR results when extracted alone or in $4 \mathrm{~g}$ soil (Figure 4). In contrast, the weight equivalent of 32 sclerotia was detected more efficiently in soil; about $62 \%$ more Rtul sclerotial DNA was detected in soil compared to pure sclerotia not mixed with anything. The detection of lab-grown sclerotia became unreliable when the number of sclerotia per gram of soil was less than two.

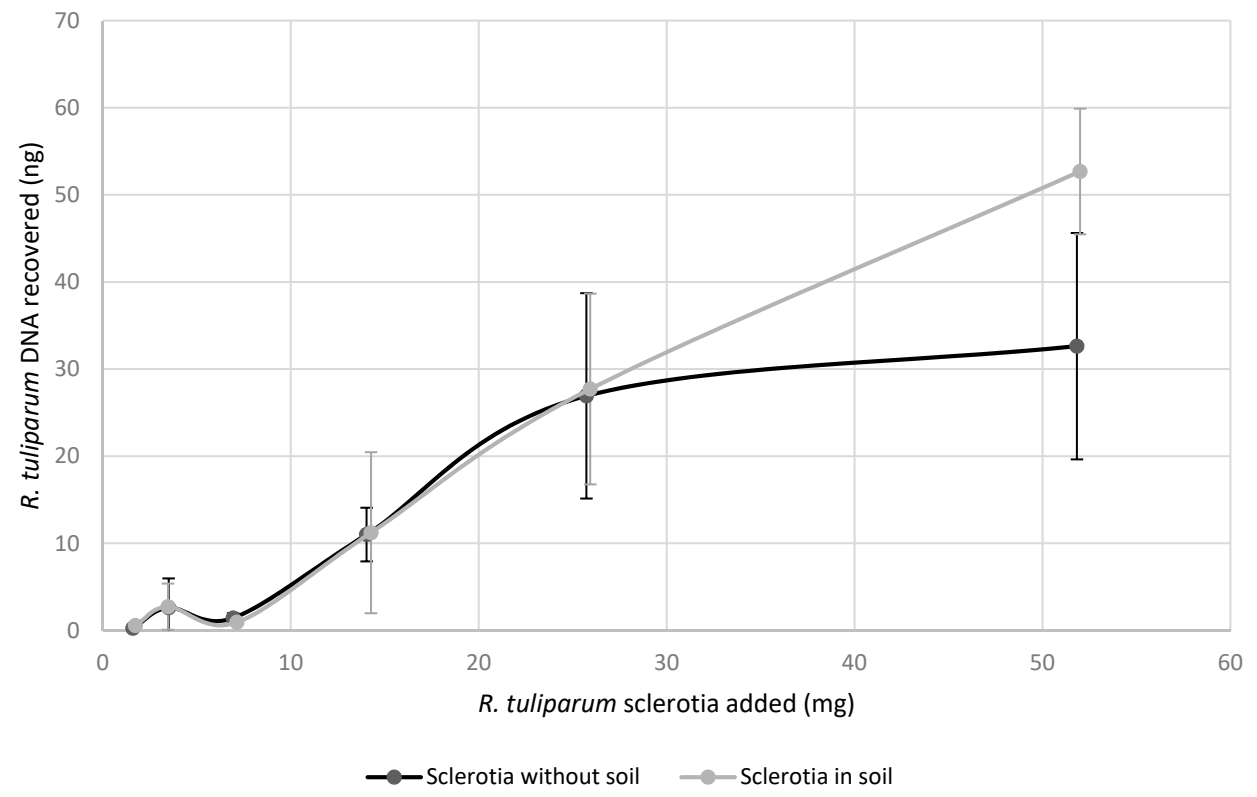

Figure 4. The Rtul qPCR assay was used to evaluate the effect of soil on the detection of Rhizoctonia tuliparum sclerotial DNA. The average amount of R. tuliparum DNA detected when the weightequivalent of one to 32 sclerotia was added to four grams of soil was fairly consistent, with the exception of the highest amount of sclerotia that yielded more DNA in the presence of soil. 


\subsection{Detection of R. tuliparum in Bulbs}

To determine the detection limit of the Rtul assay using infected bulb tissue, an increasing amount of tulip bulb tissue was extracted with eight lab-grown Rtul sclerotia. An inverse sensitivity of detection of Rtul was observed when sclerotial DNA was extracted in the presence of increasing amounts of bulb tissue. At the maximum amount tested, one-half a tulip bulb, detection of DNA from eight lab-grown sclerotia decreased by an average of $84 \%$ (calculated as $100-[100 \times 0.45$ bulb fraction/2.8 ng recovered DNA]), indicating possible carryover of PCR inhibitors in sample preparations in the presence of bulb tissues (Figure 5).

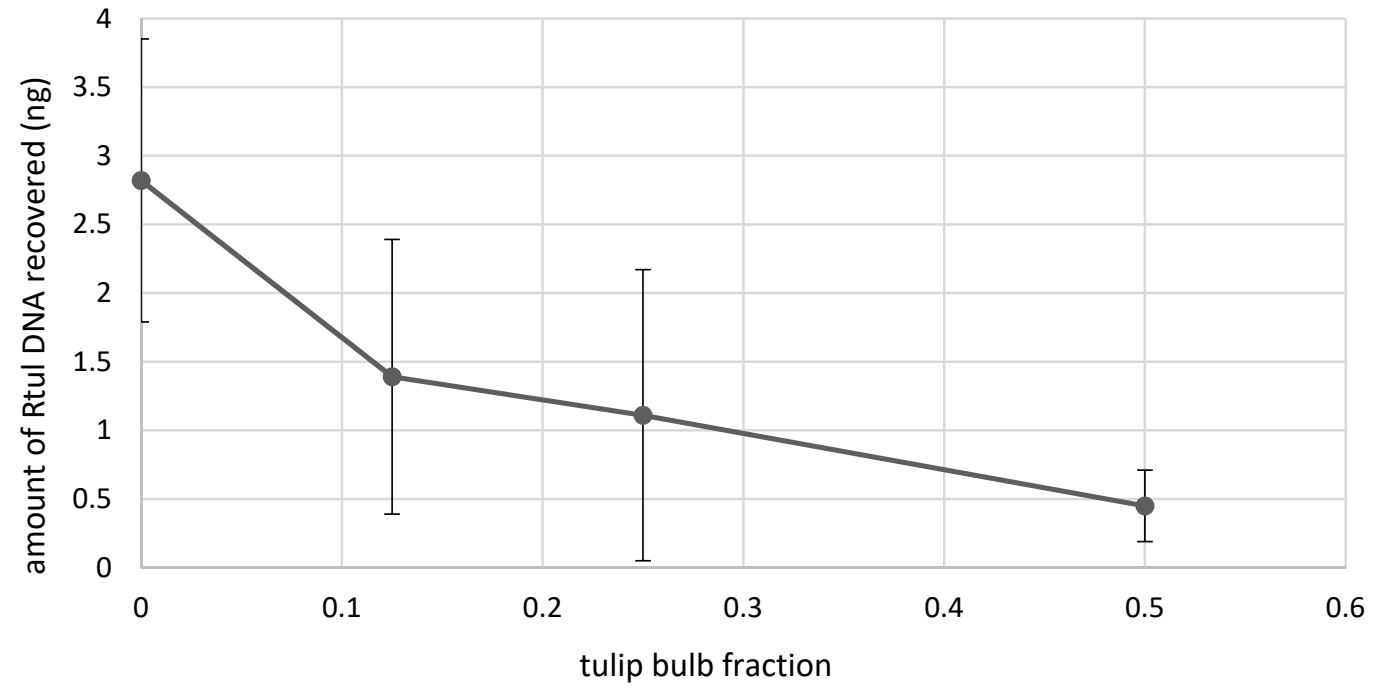

Figure 5. Analysis of the effect of tulip bulb tissue on sensitivity of qPCR detection of Rhizoctonia tuliparum DNA. $14.25 \mathrm{mg}$ sclerotia (equivalent of 8 average size lab-grown sclerotia) were added to various fractions of tulip bulb tissue to determine the limit of detection of sclerotial DNA in infected bulbs by Rtul qPCR. The amount of $R$. tuliparum DNA detected was compared to the amount of DNA in sclerotia in the absence of bulb tissue. The presence of bulb tissue reduced the ability to detect R. tuliparum.

\subsection{Phylogenetic Analyses}

The Bayesian and MP trees were essentially identical in topology; therefore, we only present the Bayesian tree. The bootstrap support values of $75 \%$ or higher from the MP analyses are indicated on the Bayesian tree with the symbol $\left({ }^{*}\right)$ under the branches (Figure 6). The Bayesian tree showed that all three geographically separated isolates of Rtul [KX767078 (Washington, DC, USA), EU191041 (Europe) and MH854847 (Ithaca, NY, USA)] formed a monophyletic group with high posterior probability and bootstrap values. The clade had a strong sister relationship with the clade of two $C$. anceps isolates, with posterior probability of 0.99 and bootstrap value of $>70 \%$. No further relationship can be inferred from the tree due to lack of phylogenetic support with other clades.

\subsection{Morphometric Analyses of the ITS2 Region}

The ITS2 sequence length was 237 bases for $C$. anceps, and 238 bases for each of the three Rtul accessions. The GC content of the ITS2 region was $42.6 \%$ for C. anceps, and $46.2 \%$, $45.8 \%$, and $45.8 \%$ for the isolates of Rtul with GenBank Accessions KX767078, EU191041, and MH854847, respectively (Table S1).

In comparison with the secondary structure of the ITS2 region of $C$. anceps isolate CBS 152.32 (MH855251), the ITS2 secondary structure of Rtul isolate I-399 (KX767078) had a CBC and a hCBC in helix II, lost three base pairs in helix III, and lost one base pair in helix IV (Figure 7; Table S2). The presence of the CBC, hCBC, and a loss/gain of base pairs amongst the two species is commensurate with two distinct biological species [31]. This point is supported by the fact that they formed two distinct phylogenetic clades with strong 
bootstrap value at the primary ITS2 sequence level (Figure 6). However, phylogenetically, the two species are closer to one another than the many other species of Ceratobasidium. The C. anceps and the three isolates of Rtul have maintained a conserved AAGT in the terminal loop of helix III. The conserved triplets of AAT in helix I, CAC in helix II, and TAG in helix IV were observed in respective ITS2 terminal loops of $C$. anceps and the three Rtul isolates. (Figure 7; Table S3).

AB213575 Waitia circinata AB213597 W. circinata

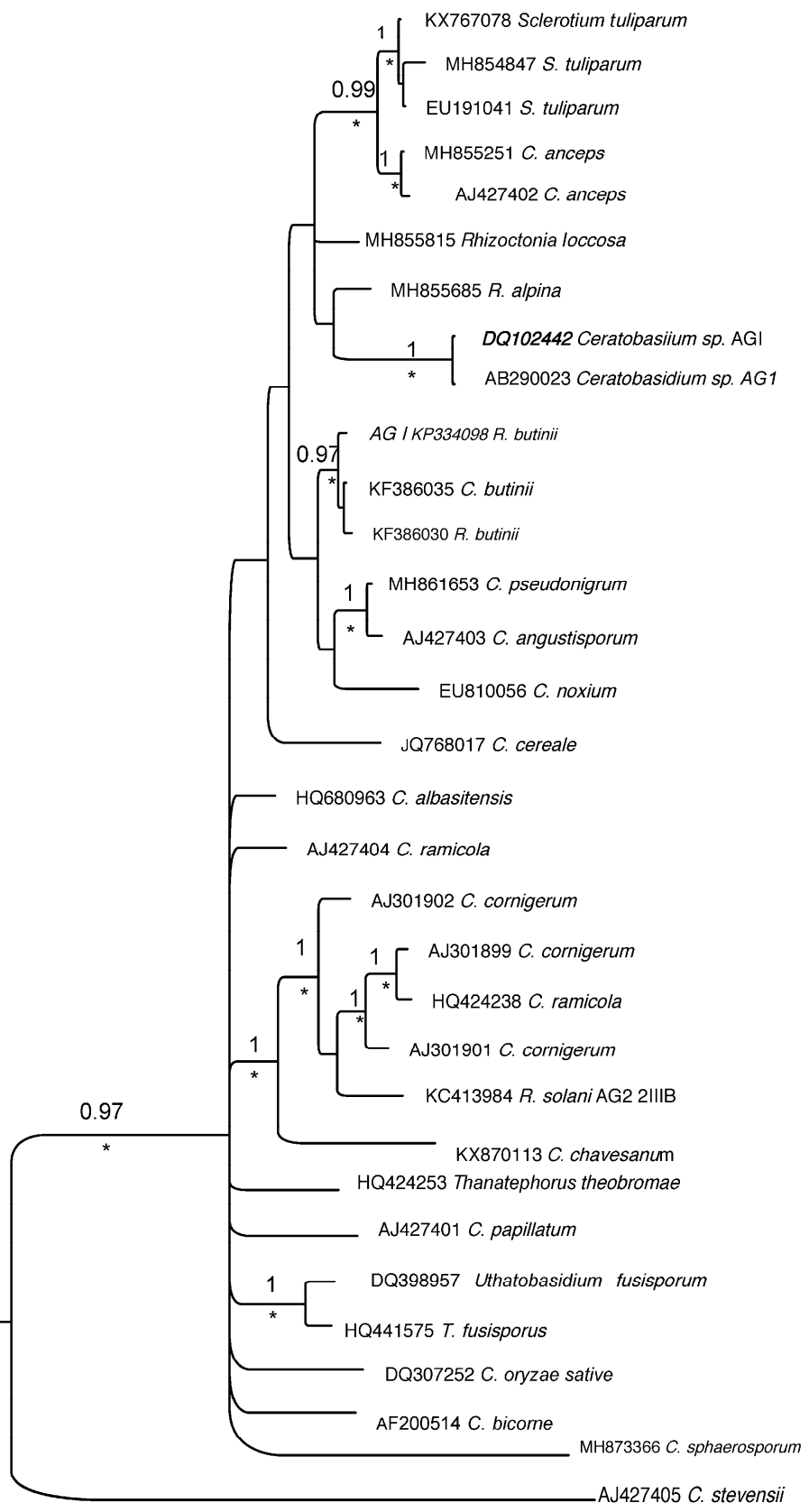

Figure 6. Bayesian tree obtained based on internal transcribed spacer sequences illustrating phylogeny of Rhizoctonia tuliparum within closely related species. One million generations with $25 \%$ of the initial trees discarded in the burn-in phase were used for analysis. Posterior probabilities $>0.95$ are shown above the branches. The tree was rooted with two isolates of Waitea circinata. The symbol ${ }^{*}$ ) under branches indicates bootstrap support $\geq 70 \%$ obtained from parsimony analysis. 


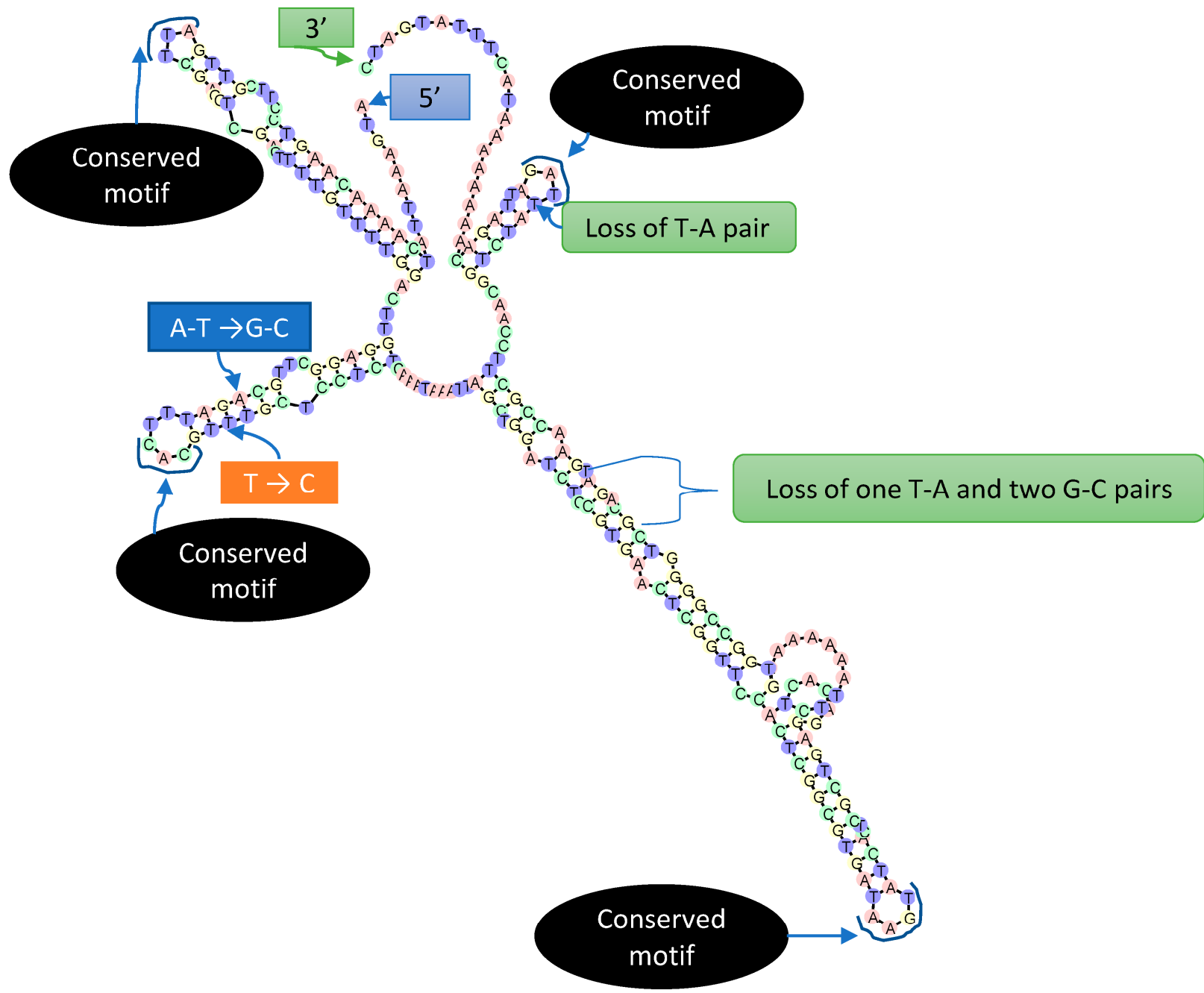

Figure 7. The ITS2 secondary structure of Ceratobasidium anceps, isolate CBS 152.32 (GenBank Accession MH855251). as predicted by the ITS2 DB 'Predict' utility. The nucleotides are highlighted in green $(\mathrm{C})$, orange $(\mathrm{G})$, violet $(\mathrm{T})$, and pink $(\mathrm{A})$. The structural changes in ITS2 of Rhizoctonia tuliparum isolate I-399 (GenBank Accession KX767078) are indicated by compensatory base change (CBC) in the blue box, the hemi-compensatory base change (hCBC) in the orange box, and the loss of base pairs in light green boxes. The conserved terminal loop sequences are marked with curved lines and indicated in black oval boxes in all four helices.

In comparison with the ITS2 secondary structure of the Rtul Washington isolate I-399 (KX767078), the corresponding structures of European isolate 29,792 (EU191041) only have a point mutation in the loop region (transversion, $\mathrm{C} \rightarrow \mathrm{A}$ ) of helix III, resulting in the gain of a base pair (A-T) (Figure 8; Table S4). However, in comparison with the ITS2 secondary structure of isolate I-399, the ITS2 secondary structure of isolate CBS206.25 (MH854847) showed structural changes in helices II, III, and IV. Thus, a G $\rightarrow$ C transversion in helix II resulted in the loss of a G-C base pairing in helix II. In helix III, (i) a transversion in the loop region $(C \rightarrow A)$ resulted in the gain of a base pair $(A-T)$, (ii) an $A \rightarrow C$ transversion resulted in the loss of a base pairing (A-T) needed for a single base pair pseudoknot-like structure, and (iii) a $C \rightarrow G$ transversion resulted in the net loss of a $C-G$ base pair in helix III. Therefore, a net loss of one base pair was observed in helix III of isolate CBS206.25. A missing pseudoknot in helix III of the CBS206.25 isolate of Rtul may be a significant genetic shift. Moreover, a $\mathrm{G} \rightarrow \mathrm{A}$ transition in helix IV of the latter isolate resulted in the loss of a C-G base pair. 


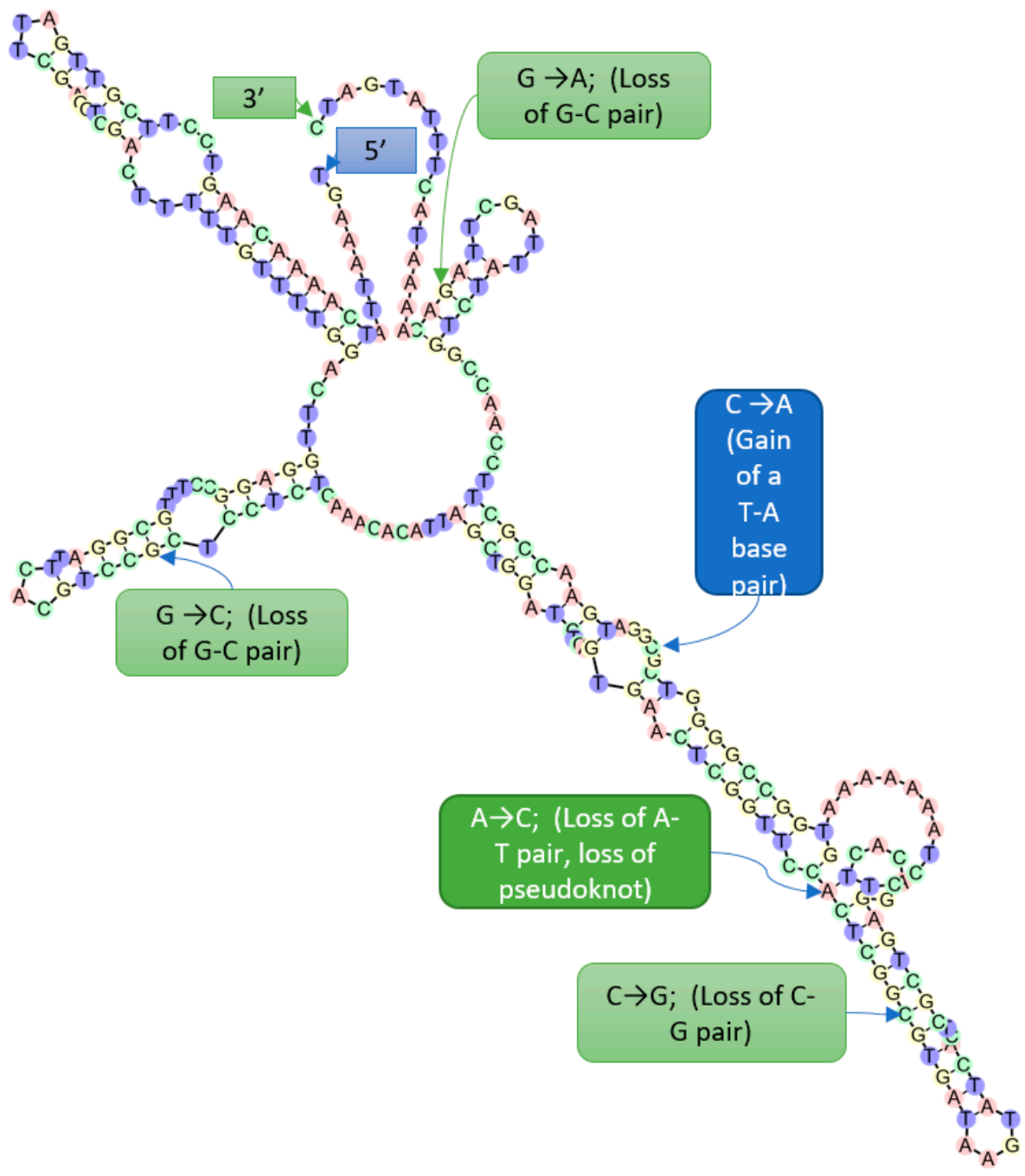

Figure 8. The ITS2 secondary structure of Rhizoctonia tuliparum isolate I-399 from Washington State (GenBank Accession KX767078), as predicted by the ITS2 DB 'Predict' utility. The nucleotides are highlighted in green $(\mathrm{C})$, orange $(\mathrm{G})$, violet $(\mathrm{T})$, and pink (A). The structural changes in ITS2 of the R. tuliparum isolate 29,792 from Europe [EU19104], and the isolate CBS206.25 from New York [MH854847] are indicated as gain of a base pair due to a hemi-compensatory base change (hCBC) in the blue box and loss of base pairs due to hCBCs in the light green boxes. A hCBC resulting in loss of a pseudoknot in the isolate CBS206.25 [MH854847] is indicated in the dark green box.

We also noted that the single base pair pseudoknot-like structure was formed in helix III of Ceratobasidium AGs A, Ba, Bb, B(o), C, G, H, I, L, Q, uninucleate Rhizoctonia 1(UNR1) isolates (Table S5), C. anceps, C. fluccosa, R. alpine, R. butini, C. pseudocornigerum, and C. noxium isolates which phylogenetically belonged in the extended clade containing the Rtul isolates (Figure 6). Interestingly, a pseudoknot-like structure did not form in the ITS2 helix III from AG groups E, Fa, Fb, K, P, O, R, S, U, and UNR2 accessions AF200515 and AF200517 (Table S5).

\section{Discussion}

We developed a robust TaqMan ${ }^{\circledR}$ real-time qPCR assay to specifically detect and quantify Rtul DNA based on a unique sequence of the internal transcribed spacer region. Specificity to Rtul with the exclusion of other Rhizoctonia genera, species, AGs, and subgroups was established by testing the assay on nontarget isolates, of which none amplified. The Rtul PCR primers and the probe exactly matched the Rtul ITS2 sequence. Moreover, the NCBI BLAST search (dated 14 January 2022) of the Rtul probe showed $100 \%$ sequence 
homology with ITS sequence region of C. pseudocornigerum (MH861653), C. angustisporum (NR_154601), and several species of mycorrhizal Ceratobasidium, mostly from orchid hosts (Table S6). The Rtul probe also matched 13 out of 17 bases (data not shown) with its close phylogenic relative, C. anceps (Figure 6), which is a pathogen of persimmon (Diospyros kaki) and tea [32]. Because of host differences, the presence of above pathogens in proximity to $R t u l$ pathogen would be remote. Therefore, the qPCR assay should be considered specific for Rtul when tested with soils from iris fields. All Rtul samples tested were amplified, and a dilution series of $R t u l$ DNA revealed a limit of detection of $1 \mathrm{fg}$ DNA. The Rtul qPCR assay presents a signification advance in molecular diagnostics of the pathogen and is appropriate for identification of isolates or sclerotia, as well as detection of the pathogen in soil or plant tissue.

Most Rhizoctonia pathogenicity studies use inoculum grown on culture plates, which produce sclerotia which are slightly different in appearance from those naturally occurring in soil. In our observation, lab-grown sclerotia are brown and corky in texture, while natural sclerotia have a darker and harder outer rind. In addition, natural sclerotia range from light brown to black in coloration. Because the intended application of the qPCR assay is to detect natural sclerotia, but validation experiments were performed with lab-grown sclerotia, the assay's ability to detect Rtul DNA in both naturally found and lab-grown sclerotia was compared. The sensitivity of Rtul detection from light brown sclerotia was two-fold and seven-fold higher then corresponding natural black sclerotia and lab-grown sclerotia, respectively; thus, confirming the suitability of the qPCR assay to detect Rtul in the field.

The presence of soil did not affect the efficiency of DNA extraction or detection of sclerotia using qPCR, as observed by Guo et al. [33] for the detection and quantification of $R$. cerealis in soil. In fact, sclerotial DNA extraction in the presence of soil seemed to remove or neutralize PCR inhibitors. Fungi sequester many secondary metabolites in sclerotia that act as a chemical defense system against competitors, fungivorous predators and parasites [34], although the effect of such chemicals on PCR has not been investigated [35].

The ability to detect Rtul DNA decreased with increased tulip bulb tissue, such that the equivalent of almost ten sclerotia would need to be present if one whole tulip bulb was extracted. This limited sensitivity has the potential to limit the effectiveness of the Rtul assay in quantifying inoculum levels in planting stock. It is likely the decreased sensitivity of the Rtul assay associated with increased bulb tissue may be due to the presence of qPCR inhibitors in the dormant tulip bulb tissues [36]. A variety of protocols have been developed to remove inhibitors from nucleic acids before PCR [37]. Additional research is needed to determine if removal of potential inhibitors from tulip bulb tissues to increase the sensitivity of the whole bulb assay, and thereby maximize the likelihood of detecting bulb infections, would be beneficial. Moreover, Tellenbach et al. [38] reported increased sensitivity of qPCR detection from sclerotial DNA when probes were made from a single-copy gene as opposed to a multicopy gene like ITS. This enhancement effect was attributed to dilution of PCR inhibitors after the first amplification step. With the genome information of Rtul potentially available, future enhancement of pathogen detection from sclerotial DNA may be possible with probes designed from single copy genes [39].

We also conducted ITS (ITS1-5.8S-ITS2)-based phylogenetic characterization and ITS2based molecular morphometric characterization of three geographically distinct $R t u l$ isolates and demonstrated divergent relationships among them as well as their taxonomic position with fungi belonging to Ceratobasidiaceae. The Bayesian inference of phylogeny revealed that the three isolates of $R t u l$ investigated have originated as a distinct clade, but closer to another distinct clade consisting of a binucleate Rhizoctonia, C. anceps. Besides, the Rtul isolates were more distant from other Ceratobasidium spp., including Ceratobasidium AGs A to U. This hypothesis is well-supported from the ITS2 molecular morphometric analyses. ITS2 of $C$. anceps has lower GC content and is one nucleotide shorter than those of the Rtul isolates (Table S1). Also, secondary structures of the two species have at least 
one $\mathrm{CBC}$ and one $\mathrm{hCBC}$ in helix II, indel of three base pairs in helix III, and indel of one base pair in helix IV (Figure 7).

Recent studies have demonstrated that ITS2 sequence evolves very quickly amongst eukaryotes, making it an excellent marker that is widely used in low level phylogenetic analyses and DNA barcoding of organisms, including fungi [40-43]. By the same token, any hypervariable feature may also be problematic for investigating deeper phylogeny. This could be overcome by its conserved secondary structure. The conservation of ITS 2 secondary structure is a critical component of rRNA processing [41]. Thus, any compensatory base change $(\mathrm{CBC})$ and hemi-compensatory base change (hCBC) in the two most conserved helices, namely helix II and helix III, have been correlated with delineation of species [44]. Speciation in eukaryotes, particularly amongst plants and fungi, has been correlated with even one CBC in the relatively conserved pairing positions of the ITS2 transcript secondary structure [45]. The probability to discriminate between two species with a single CBC between the members of an ITS2 sequence-structure pair has a confidence of 93\% [31,45]. On the other hand, if there is no $\mathrm{CBC}$, then individuals may belong to the same species with $76 \%$ confidence [45]; Wolf et al. [31]. Molecular morphometric analyses utilize the ITS2 primary sequence as well as secondary structural constraints, homologous locations, indels and substitution to distinguish closely related fungal and other species [21,22]. As a proof of concept for Rhizoctonia species, Ahvenniemi et al. [46] showed that the potato (PT) and tobacco (TB) subgroups of $R$. solani AG 3 differ in the ITS2 secondary structure helix I by two CBCs. Moreover, the $\mathrm{CBC}$ in potato strains of AG 3 distinguish them from other AGs of $R$. solani, confirming the hypothesis that the latter is functionally a composite species. Interestingly, our investigations on the ITS2 molecular morphometrics of the three geographically distant $R t u l$ isolates demonstrated that major genetic shifts have taken place resulting in significant alteration of respective ITS2 secondary structures. Thus, although the ITS (ITS-5.8S-ITS2) primary sequences of all the three isolates of Rtul formed a well-supported clade in the phylogenetic tree (Figure 6), molecular morphometric analyses clearly differentiated them as three potentially distinct sexual species within R. tuliparum, sensu lato, per Müller et al. [45] and Wolf et al. [31] (Figure 8; Table S4), and call for further investigation. Moreover, from disease epidemiology and management viewpoints, our findings call for accurate identification of pathogen genotypes as well as determination of sensitivities of genetically diverse isolates of Rhizoctonia pathogens to commonly used fungicides $[13,43,47-50]$.

The significance of the formation of single base pair pseudoknot-like structure in the stem III of ITS2 in Rtul and phylogenetically related species (Figure 6; Table S5) is not understood at present but may serve as an additional criterion to differentiate groups or strains of Ceratobasidium spp. Sharon et al. [51] phylogenetically clustered the Ceratobasidium isolates AG-A to AG-U in six groups. In this regard, it is interesting to note that the structure was present in group 4 (AG-D), group 5 [AG-B (including its three subgroups) and AG-Q], and group 6 (AG-C, AG-H, and AG-I) and absent in group 3 (AG-E, AG-F, AG-P AG-U, AG-R, and AG-S). Mixed results were also noted because in group 1 (e.g., AG-A has the pseudoknot, but not in AG-K), and in group 2 (e.g., AG-G and AG-L has the pseudoknot but absent in AG-O).

Taken together, both the development of a sensitive qPCR detection method and determination of the genetic diversity of the Rtul pathogens as documented in this investigation are significant for disease management. While cultural practices such as deep plowing to bury sclerotia, shallow planting, and flooding help control this disease, treatments such as soil fumigation, fungicide bulb dips or in-furrow or broadcast applications of fungicides to the soil at the time of planting are also often used as methods of disease control $[3,4,9,12,52,53]$. In this context, additional research is needed to determine soilborne inoculum thresholds through qPCR, as developed in this investigation, for disease development. Given the spatial distribution of the disease, additional research is also needed to define a sampling protocol that could be used along with this qPCR diagnostic assay to accurately predict the risk of disease development. Furthermore, the presence 
of genetic diversity of Rtul pathogens as determined in this report also calls for assaying differential sensitivity of $R t u l$ isolates to various fungicides and finding the most efficient fungicide for each Rtul genotype. A sensitive detection method, along with the use of the most effective fungicide, would ultimately give rise to environmentally and economically sound management of gray bulb rot in tulips and bulbus irises [54-56].

Supplementary Materials: The following are available online at https:/ /www.mdpi.com/article/ 10.3390/jof8020163/s1. Table S1: The ITS2 sequence length and base composition of C. anceps and three R. tuliparum (Rtul) isolates, Table S2: Base-pairing in the ITS2 RNA secondary structures of Rtul Washington isolate (KX767078) in comparison to that of C. anceps (MH855251), Table S3: The conserved terminal loop sequences in all isolates of C. anceps (MH855251 and AJ427402), and Rtul (KX767078, EU191041, and MH854847), Table S4: Base-pairing in the ITS2 RNA secondary structures and the conserved terminal loop sequences of the European (EU191041) and the New York (MH854847) isolates of Rtul with respect to the Washington isolate (KX767078), Table S5: Presence or absence of pseudoknot-like structure in helix III of Ceratobasidium binucleate and uninucleate isolates within the greater clade containing Rtul in Figure 6. Table S6: GenBank Accessions of the ITS (ITS1-5.8S-ITS2) regions showing complete sequence match with the Rtul Q-PCR Probe. Figure S1: Selected ITS regions from alignment file of Rhizoctonia pathogens for designing primers and probes for the Rtul Q-PCR detection, Figure S2: Morphologies of "lab-grown" sclerotia and a mixture of "natural light" and "natural dark" sclerotia.

Author Contributions: K.C. conceptualization, data generation, analysis, interpretation and writing initial draft; A.D. data generation and analysis; D.K.L. data generation, analysis, interpretation, and writing; A.I. data generation, analysis, interpretation, and writing; D.P.R. data curation and editing; G.C. conceptualization, resources and funding acquisition, writing, editing. All authors have read and agreed to the published version of the manuscript.

Funding: A portion of the research was funded by Cooperative Agreements between USDA-ARS and Washington State University (58-8042-6-091 and 58-8042-1-059) and funding from the Northwest Agricultural Research Foundation and Wally Staatz Turfgrass/Ornamental Endowment. Funding was also provided by USDA-ARS in-house project $804221220181000 \mathrm{D}$.

Institutional Review Board Statement: Not applicable.

Informed Consent Statement: Not applicable.

Data Availability Statement: All relevant data generated or analyzed during this study are included in this article.

Acknowledgments: In-kind support from Washington Bulb Company and Washington State Bulb Grower Association is appreciated.

Conflicts of Interest: The authors declare no conflict of interest.

\section{References}

1. Whetzel, H.H.; Arthur, J.M. Gray Bulb-Rot of Tulips Caused By Rhizoctonia tuliparum (Klebh.) N. Comb; Cornell University: Ithaca, NY, USA, 1925.

2. Buddin, W. The grey bulb rot of tulips and its control. J. Minist. Agric. Fish. 1937, 44, 1154-1159.

3. Moore, W.C. Grey Bulb Rot of tulip. J. Hortic. Soc. 1950, 75, 113-117.

4. Moore, W.C. Diseases of Bulbs, 2nd ed.; Dickens, J.S.W., Ed.; Her Majesty's Stationary Office: London, UK, 1979; 205p.

5. Boerema, G.H.; Hamers, M.E.C. Check-list for scientific names of common parasitic fungi. Series 3a: Fungi on bulbs: Liliaceae. Nether. J. Plant Pathol. 1988, 94, 1-29. [CrossRef]

6. Gladders, P.; Coley-Smith, J.R. Rhizoctonia tuliparum: A winter-active pathogen. Trans. Brit. Mycol. Soc. 1978, 71, 129-139. [CrossRef]

7. Wakker, J.H. Onderzoek der Ziekten van Hyacinthen en Andere Bol- En Knolgewassen; Algemeene Vereeniging voor Bloembollencultuur: Haarlem, The Netherlands, 1884; 26p.

8. Whetzel, H.H.; Arthur, J.M. The grey bulb-rot of tulips. Phytopathology 1924, 14, 30-31.

9. McGovern, R.J.; Elmer, W.H. Diseases of Tulip. In Handbook of Florists' Crops Diseases. Handbook of Plant Disease Management; McGovern, R., Elmer, W., Eds.; Springer: Cham, Switzerland, 2017. [CrossRef]

10. Coley-Smith, J.R.; Humphreys-Jones, D.R.; Gladders, P. Long-term survival of sclerotia of Rhizoctonia tuliparum. Plant Pathol. 1979, 28, 128-130. [CrossRef] 
11. Blok, W.; Coenen, T.C.M.; Termorshiuzen, A.J.; Lamers, J.G. The potential of biological soil disinfestation to manage fusarium foot and root rot in asparagus. Acta Hortic. 2008, 776, 135-144. [CrossRef]

12. Chastagner, G.A.; DeBauw, A. Alternatives to PCNB for controlling Gray Bulb Rot on tulips. Acta Hort. (ISHS) 2011, 886, 311-317. [CrossRef]

13. Lakshman, D.K.; Cloyd, R.A.; Chastagner, G.A. Integrated management of diseases and pests on ornamental geophytes: Challenges and progress. Acta Hortic. 2019, 1237, 13-32. [CrossRef]

14. Leclerc, M.; Doré, T.; Gilligan, C.A.; Lucas, P.; Filipe, J.A. Host growth can cause invasive spread of crops by soilborne pathogens. PLoS ONE 2013, 8, e63003. [CrossRef]

15. Termorshuizen, A.J.; Jeger, M.J. Assessing inoculum of soilborne plant pathogens: Theory and practice. Acta Hortic. 2014, 1044, 75-80. [CrossRef]

16. Wei, F.; Fan, R.; Dong, H.T.; Shang, W.-J.; Xu, X.M.; Zhu, H.Q.; Yang, J.R.; Hu, X.P. Threshold microsclerotial inoculum for cotton Verticillium wilt determined through wet-sieving and real-time quantitative PCR. Phytopathology 2015, 105, 220-229. [CrossRef] [PubMed]

17. Panth, M.; Hassler, S.C.; Baysal-Gurel, F. Methods for management of soilborne diseases in crop production. Agriculture 2020, 10, 16. [CrossRef]

18. Heid, C.A.; Stevens, J.; Livak, K.J.; Williams, P.M. Real time quantitative PCR. Genome Res. 1996, 10, 986-994. [CrossRef]

19. Burton, R.J.; Coley-Smith, J.R. Antibiotics in sclerotia and mycelium of Rhizoctonia species. Trans. Br. Mycol. Soc. 1985, 85, 447-453. [CrossRef]

20. Dijst, G.; Schneider, J.H.M. Flower bulb diseases incited by Rhizoctonia species. In Rhizoctonia Species: Taxonomy, Molecular Biology, Ecology, Pathology and Disease Control; Sneh, B., Jabaji-Hare, S., Neate, S.M., Dijst, G., Eds.; Kluwer: Dordrecht, The Netherlands, 1996; pp. 279-288.

21. Sundaresan, N.; Jagan, E.G.; Kathamuthu, G.; Pandi, M. Internal transcribed spacer 2 (ITS2) molecular morphometric analysisbased species delimitation of foliar endophytic fungi from Aglaia elaeagnoidea, Flacourtia inermis and Premna serratifolia. PLoS ONE 2019, 14, e0215024. [CrossRef] [PubMed]

22. Billoud, B.; Guerrucci, M.A.; Masselot, M.; Deutsch, J.S. Cirrepede phylogeny using a novel approach: Molecular morphometrics. Mol. Biol. Evol. 2020, 17, 1435-1445. [CrossRef]

23. Haugland, R.A.; Siefring, S.C.; Wymer, L.J.; Brenner, K.P.; Dufour, A.P. Comparison of Enterococcus measurements in freshwater at two recreational beaches by quantitative Polymerase Chain Reaction and membrane filter culture analysis. Water Res. 2005, 39, 559-568. [CrossRef]

24. Ruijter, J.M.; Ramakers, C.; Hoogaars, W.M.; Karlen, Y.; Bakker, O.; van den Hoff, M.J.; Moorman, A.F. Amplification efficiency: Linking baseline and bias in the analysis of quantitative PCR data. Nucleic Acids Res. 2009, 37, e45. [CrossRef]

25. Thompson, J.D.; Gibson, T.J.; Plewniak, F.; Jeanmougin, F.; Higgins, D.G. The Clustal X Windows interface; flexible strategies for multiple sequence alignment aided by quality analysis tools. Nucl. Acids Res. 1997, 24, 4876-4882. [CrossRef]

26. Maddison, W.P.; Maddison, D.R. Mesquite: A Modular System for Evolutionary Analysis. 2019, Version 3.61. Available online: http:/ / www.mesquiteproject.org (accessed on 10 November 2021).

27. Huelsenbeck, J.P.; Ronquist, F. MrBayes: Bayesian inference of phylogeny trees. Bioinformatics 2001, 17, 754-755. [CrossRef] [PubMed]

28. Swofford, D.L. PAUP*: Phylogenetic Analysis Using Parsimony ( ${ }^{*}$ and Other Methods); Version 4.0b10; Sinauer Associates: Sunderland, MA, USA, 2002. [CrossRef]

29. Vu, D.; Groenewald, M.; de Vries, M.; Gehrmann, T.; Stielow, B.; Eberhardt, U.; Al-Hatmi, A.; Groenewald, J.Z.; Cardinal, G.; Houbraken, J.; et al. Large-scale generation and analysis of filamentous fungal DNA barcodes boosts coverage for kingdom fungi and reveals thresholds for fungal species and higher taxon delimitation. Stud. Mycol. 2019, 92, 135-154. [CrossRef]

30. Ankenbrand, M.J.; Keller, A.; Wolf, M.; Schultz, J.; Förster, F. ITS2 database V: Twice as much. Mol. Biol. Evol. 2015, 32, 3030-3032. [CrossRef] [PubMed]

31. Wolf, M.; Chen, S.; Song, J.; Ankenbrand, M.; Müller, T. Compensatory base changes in ITS2 secondary structures correlate with the biological species concept despite intragenomic variability in ITS2 sequences-A proof of concept. PLoS ONE 2013, 8, e66726. [CrossRef] [PubMed]

32. Ceresini, P.C.; Costa-Souza, E.; Zala, M.; Furtado, E.L.; Souza, N.L. Evidence that the Ceratobasidium-like white-thread blight and black rot fungal pathogens from persimmon and tea crops in the Brazilian Atlantic Forest agroecosystem are two distinct phylospecies. Genet. Mol. Biol. 2012, 35, 480-497. [CrossRef] [PubMed]

33. Guo, Y.; Sun, L.W.H.; Wang, N.; Yu, H.; Chen, H. Detection and quantification of Rhizoctonia cerealis in soil using real-time PCR. J. Gen. Plant Pathol. 2012, 78, 247-254. [CrossRef]

34. Calvo, A.M.; Cary, J.W. Association of fungal secondary metabolism and sclerotial biology. Front. Microbiol. 2015, 6, 62. [CrossRef]

35. Shu, C.; Sun, S.; Chen, J.; Chen, J.; Zhou, E. Comparison of different methods for total RNA extraction from sclerotia of Rhizoctonia solani. Elec. J. Biotechnol. 2014, 17, 50-54. [CrossRef]

36. Wei, T.; Lebas, B.S.M.; Shiller, J.B.; Quinn, B.D.; Clover, G.R.G. Detection of five viruses infecting dormant bulbs by TaqMan-based real-time RT-PCR. Australas. Plant Pathol. 2012, 41, 93-98. [CrossRef]

37. Schrader, C.; Schielke, A.; Ellerbroek, L.; Johne, R. PCR inhibitors-Occurrence, properties, and removal. J. Appl. Microbiol. 2012, 113, 1014-1026. [CrossRef] 
38. Tellenbach, C.; Grünig, C.R.; Sieber, T.N. Suitability of quantitative real-time PCR to estimate biomass of fungal root endophytes. Appl. Environ. Microbiol. 2010, 76, 5764-5772. [CrossRef] [PubMed]

39. Feau, N.; Decourcelle, T.; Husson, C.; Desprez-Loustau, M.-L.; Dutech, C. Finding single copy genes out of sequenced genomes for multilocus phylogenetics in non-model fungi. PLoS ONE 2011, 6, e18803. [CrossRef] [PubMed]

40. Yang, R.H.; Su, J.H.; Shang, J.J.; Wu, Y.Y.; Li, Y.; Bao, D.P.; Yao, Y.J. Evaluation of the ribosomal DNA internal transcribed spacer (ITS), specifically ITS1 and ITS2, for the analysis of fungal diversity by deep sequencing. PLoS ONE 2018, 13, e0206428. [CrossRef] [PubMed]

41. Mbareche, H.; Veillette, M.; Bilodeau, G.; Duchaine, C. Comparison of the performance of ITS1 and ITS2 as barcodes in amplicon-based sequencing of bioaerosols. PeerJ 2020, 8, e8523. [CrossRef] [PubMed]

42. Zhang, W.; Tian, W.; Gao, Z.; Wang, G.; Zhao, H. Phylogenetic utility of rRNA ITS2 sequence-structure under functional constraint. Int. J. Mol. Sci. 2020, 21, 6395-6407. [CrossRef] [PubMed]

43. Singh, V.; Lakshman, D.K.; Roberts, D.P.; Ismaiel, A.; Hooda, K.S.; Gogoi, R. Morphopathological and molecular morphometric characterization of Waitea circinata var. prodigus causing a novel sheath spot disease of maize in India. Plant Dis. 2021. [CrossRef]

44. Coleman, A.W. Is there a molecular key to the level of "biological species" in eukaryotes? A DNA guide. Mol. Phylogenet. Evol. 2009, 50, 197-203. [CrossRef]

45. Müller, T.; Philippi, N.; Dandekar, T.; Schultz, J.; Wolf, M. Distinguishing species. RNA 2007, 13, 1469-1472. [CrossRef]

46. Ahvenniemi, P.; Wolf, M.; Lehtonen, M.J.; Wilson, P.; German-Kinnari, M.; Valkonen, J.P.T. Evolutionary diversification indicated by compensatory base changes in ITS2 secondary structures in a complex fungal species, Rhizoctonia solani. J. Mol. Evol. 2009, 69, 150-163. [CrossRef]

47. Kammerer, S.J.; Burpee, L.L.; Harmon, P.F. Identification of a new Waitea circinata variety causing basal leaf blight of seashore paspalum. Plant Dis. 2011, 95, 515-522. [CrossRef]

48. Amaradasa, B.S.; Lakshman, D.K.; Horvath, B.J.; Amundsen, K.L. Development of SCAR markers and UP-PCR cross-hybridization method for specific detection of four major subgroups of Rhizoctonia from infected turfgrasses. Mycologia 2014, 106, 163-172. [CrossRef] [PubMed]

49. Amaradasa, B.S.; Lakshman, D.K.; McCall, D.; Horvath, B.J. In vitro fungicide sensitivity of Rhizoctonia and Waitea isolates collected from turfgrasses. J. Environ. Hort. 2014, 32, 126-132. [CrossRef]

50. Amaradasa, B.S.; Lakshman, D.K.; Amundsen, K. AFLP fingerprinting for identification of infra-species groups of Rhizoctonia solani and Waitea circinata. J. Plant Protect. Microbiol. 2015, 6, 3. [CrossRef]

51. Sharon, M.S.; Kuninaga, S.; Hyakumachi, M.; Naito, S.; Sneh, B. Classification of Rhizoctonia spp., using rDNA-ITS sequence analysis supports the genetic basis of the classical anastomosis grouping. Mycoscience 2008, 49, 93-114. [CrossRef]

52. van Klaveren, C. Ziegnten in bloembollen. Maandbl. Landbouw Voorl. 1949, 6, 147-153.

53. Muller, P.J.; Vink, P.; Van Zaagen, A. Flooding caused loss in viability and pathogenicity of sclerotia of Rhizoctonia tuliparum. Eur. J. Plant Pathol. 1988, 94, 45-47. [CrossRef]

54. Chastagner, G.; Hanks, G.; Daughtrey, M.; Yedidia, I.; Miller, T.; Pappu, H. Sustainable Production and Integrated Management: Environmental Issues. In Ornamental Geophytes: From Basic Science to Sustainable Horticultural Production; Kamenetsky, R., Okubo, H., Eds.; CRC Press: Boca Raton, FL, USA, 2012; pp. 363-420. [CrossRef]

55. Conijn, C. Tulip Diseases. Roodbont Publishers B.V.: Zutphen, The Netherlands, 2016; p. 149.

56. Chastagner, G.A.; Garfinkel, A. Diseases Affecting Ornamental Geophytes and Their Control. In Achieving Sustainable Cultivation of Ornamental Plants; Reid, M., Ed.; Burleigh Dodds Science Publishing: Cambridge, UK, 2020; pp. 367-414. [CrossRef] 